\title{
O fora em Blanchot, do fora afora
}

Fora Maurice Blanchot unicamente um estudioso da literatura, e, como tal, responsável por alguns dos mais instigantes ensaios críticos publicados ao longo do século XX, a presente edição da outra travessia poderia ser lida como uma tentativa de render uma justa, embora tardia, homenagem a este intelectual que sempre procurou se manter fiel à palavra empenhada, por mais que lhe tenha custado tal esforço. $\mathrm{O}$ nome Blanchot, afinal, de fato alude a um excelente ensaísta, mas, além disso, ou melhor, ao lado disso ou conjugado a isso, refere-se a um escritor cujas ficçóes, se e quando conhecidas, espantam, isto é, apavoram e incomodam seus possíveis e surpresos leitores. O pensamento ficcional blanchotiano, esse desastre, pensamento drástico, lúcido e lúdico a um só tempo, com plena energia expóe e expóe-se nos moldes do exílio e da errância que insistentes o perpassam. Em seu excesso, para repetir a formulação do próprio autor, desse pensamento ficcional talvez possa ser dito que "Não está excluído, senão como algo que não entraria em parte alguma”. ${ }^{1}$

Não surpreende, portanto, o fato, por outro lado sintomático, de que, entre os diversos ensaios submetidos à avaliação do Conselho editorial da revista (número cuja magnitude chamou nossa atenção, dada a presença bastante discreta, de certo modo subliminar, dos escritos blanchotianos nos cursos de Letras brasileiros, e não apenas nas graduaçôes), e por este aprovados para publicação, a
1. BLANCHOT, Maurice. L'Écriture du désastre. Paris: Gallimard, 1980, p. 15. Tradução adaptada do seguinte fragmento: "Il n'est pas exclu, mais comme quelqu'un qui n'entrerait nulle part". 
2. BATAILLE, Georges.

"Maurice Blanchot". Lignes, 3 ,

n. 3, p.149-157, 2003.

Disponível em: http://www.

cairn.info/zen.php?ID_

ARTICLE=LIGNES1

_003_0149. Como assinala

o editor, a origem deste texto

é indeterminada. Constava na

caixa 14Q dos escritos legados por Bataille, e foi originalmente publicado na revista Gramma, no 3/4, de 1976. Todas as traduções

desse texto são nossas. absoluta maioria contemple exclusivamente seus escritos ditos teóricos. E, em tal âmbito, os textos tenderem a operar, sobretudo, a partir de alguns dos conceitos ou noçôes mais pertinentes forjados pelo escritor (o neutro, o fora, o desastre, a pluralidade, a fragmentação, a vigília, entre outros), não raro discutindo-os, e tensionando-os, com base em relaçóes estabelecidas com aportes críticos e teóricos de intelectuais que figuram entre seus mais privilegiados interlocutores (casos de Emanuel Lévinas, Jacques Derrida, Jean-Luc Nancy, Georges Bataille, Giorgio Agamben, Roland Barthes, em particular). Já uma parcela menor dos textos por nós recebidos apoia-se em escritos teóricos e críticos de Blanchot para o estudo de criaçóes artísticas específicas (com destaque para a poesia de Francisco Alvim, a ficção de Lobo Antunes e o cinema de Manoel de Oliveira), razão pela qual introduzem um viés mais propriamente analítico.

O olvido da ficção blanchotiana, ainda e também um fora em Blanchot, em alguma medida pode ser explicado pelo escasso número de traduçóes de originais de textos narrativos do escritor no âmbito do espaço editorial brasileiro, o que obriga os possíveis leitores a recorrer ou às ediçóes francesas ou a traduçóes em outras línguas que porventura dominem. Situação essa que se repete no que tange a seus livros teóricos e ensaísticos, em menor medida porém, já que alguns de seus estudos mais importantes foram entre nós traduzidos e publicados. Por razôes diversas, deste modo, nós leitores brasileiros nos vemos privados de tentar encontrar, como observou Georges Bataille, "o sentido geral de sua obra literaria" ${ }^{2}$, que para este compreende tanto a parte crítica quanto a romanesca, e que teria passado despercebido dos leitores franceses.

Embora por motivos diferentes, em que o querer dá lugar ao poder, parece assim pouco provável que entre nós o veredito polêmico de Bataille -que, conferindo maior relevo aos relatos de Blanchot, afirma que neles apenas a existência humana é motivo de discussão, existência 
essa, prossegue, cuja presença "não apavora menos, não participa menos da alegria e da tormenta, e não é menos inapreensível que aquela de Deus", diagnóstico que o leva à postulação de que "esta experiencia abrupta e desconcertante é o esencial e muito mal conhecido da obra de Blanchot, cuja crítica, qualquer que seja o interesse de análises cuja profundeza surpreendente é apenas o aspecto secundário mais acessível"3 - seja colocada em questão. E tampouco a sua conclusão taxativa, de que o que antes de tudo conta no conjunto fragmentário da obra de Blanchot, para além dos estudos críticos, "são os romances e ainda mais esses três 'relatos' em tríptico que são L’Arrêt de mort, Au moment voulu e Celui qui ne m'accompagnait pas". ${ }^{4}$

É inegável a existência de conexôes e imbricações entre as diversas modalidades textuais praticadas por Maurice Blanchot. Isso pode ser facilmente detectável não apenas pela leitura em paralelo de estudos críticos e ficçóes por ele assinados, mas se deixa também constatar, por exemplo, quando nos atemos a sua epistolografia. Nas Cartas a Vadim Kozovoi, com efeito, publicadas pela editora Lumme, em 2012, encontramos reflexóes como as que seguem, dignas de ombrearem com muitas daquelas que figuram nos mais densos ensaios críticos assinados por Blanchot: "Durar é o que há de mais importante e mais difícil. Durar, quando se trata de manter um enclave de liberdade no mundo de servidão, é mudar o tempo. Tu conheceste isso. Eu conheci isso. Não saí intacto; tu, certamente, muito menos" . Ou: "Não há país para os poetas; não há tempo, tampouco: 'para que servem os poetas em tempos de desalento?'. A ausência de tempo, a ausência de país, a ausência de 'deuses', eis o que é necessário à exigência poética e o que a torna tão incerta quanto absoluta em sua promessa de apagamento, ligada ao nosso desaparecimento que vem"6. Ou: "Tu conheces o que significa o sofrimento: ele não é egoísta, é sempre aquele de Outrem, aquele de todos. É por isso que o confio à tua discrição e à tua amizade. As palavras param, dizendo
3. Ibidem, s/p.

4. Ibidem, s/p.

5. BLANCHOT, Maurice. Cartas a Vadim Kozovoi (seguidas de $A$ palavra ascendente).

Tradução de Amanda Mendes

Casal e Eclair Antonio Almeida

Filho. São Paulo: Lumme, 2012, p. 90 .

6. Ibidem, p. 113. A citação é de Hölderlin. 
7. Ibidem, p. 57.

8. Ibidem, p. 70 . muito, não dizendo o bastante"7. Ou ainda, e enfim: "Tu certamente apreendeste, pela discrição que te é própria, que a iminência do desastre me mantém à distância deste mundo (do cosmos mesmo) a fim de estar mais próximo dele, do mesmo modo que não podemos abordar outrem senão evocando-o como o mais longínquo de quem só o respeito pelo distanciamento pode salvarguardar, no risco da perda, a infinita proximidade" ${ }^{8}$

Optamos por distribuir os textos presentes nessa edição da outra travessia em duas seçôes principais. $\mathrm{Na}$ primeira delas, intitulada "De Blanchot a Blanchot", estão publicados aqueles que se atêm a discutir, notadamente, aspectos teóricos ou conceituais depreendidos de alguns dos mais importantes estudos críticos do autor, em alguns deles abordados inclusive, como antes dito, na contraluz de outros pensadores que dialogam com o pensamento blanchotiano. Entremeando-os consta a tradução, salvo engano inédita em português, de um breve ensaio de JeanLuc Nancy, "O nome de Deus em Blanchot".

$\mathrm{Na}$ segunda, "Blanchot afora", constam os textos que realizam análises da obra ou de originais específicos de outros criadores, e que, para tanto, tomam como marco a reflexão crítica de Blanchot. Queremos agradecer a todos os colaboradores que se dispuseram a enviar seus textos para a outra travessia, e, em especial, a Silvio Mattoni e Eduardo Pellejero, que prontamente se dispuseram a nos ceder estudos inéditos de sua autoria.

Os editores 